\title{
Effect of long-term ingestion of weakly oxidised flaxseed oil on biomarkers of oxidative stress in LDL-receptor knockout mice
}

\author{
M. S. Nogueira ${ }^{1}$, M. C. Kessuane ${ }^{1}$, A. A. B. Lobo $\operatorname{Ladd}^{2}$, F. V. Lobo Ladd ${ }^{2}$, B. Cogliati ${ }^{2}$ and I. A. Castro ${ }^{1 *}$ \\ ${ }^{1}$ Laboratory of Functional Foods (LADAF), Department of Food and Experimental Nutrition, Faculty of Pharmaceutical \\ Sciences, University of São Paulo, Av. Lineu Prestes, 580, B14, 05508-900 São Paulo, Brazil \\ ${ }^{2}$ School of Veterinary Medicine and Animal Sciences, University of São Paulo, Av. Prof. Dr. Orlando Marques de Paiva, \\ 87, 05508-270 São Paulo, Brazil
}

(Submitted 14 October 2015 - Final revision received 15 February 2016 - Accepted 14 March 2016)

\section{Abstract}

The effect of oxidised fatty acids on atherosclerosis progression is controversial. Thus, our objective was to evaluate the effect of long-term consumption of weakly oxidised PUFA from flaxseed oil on oxidative stress biomarkers of LDL-receptor ${ }^{(-/-)}$mice. To test our hypothesis, mice were separated into three groups. The first group received a high-fat diet containing fresh flaxseed oil (CONT-), the second was fed the same diet prepared using heated flaxseed oil (OXID), and the third group received the same diet containing fresh flaxseed oil and had diabetes induced by streptozotocin (CONT+). Oxidative stress, aortic parameters and non-alcoholic fatty liver disease were assessed. After 3 months, plasma lipid profile, glucose levels, body weight, energy intake and dietary intake did not differ among groups. Likewise, oxidative stress, plasma malondialdehyde (MDA), hepatic MDA expressed as nmol/mg portion (ptn) and antioxidant enzymes did not differ among the groups. Hepatic linoleic acid, $\alpha$-linolenic acid, arachidonic acid and EPA acid declined in the OXID and CONT+ groups. Aortic wall thickness, lumen and diameter increased only in the OXID group. OXID and CONT+ groups exhibited higher concentrations of MDA, expressed as $\mu \mathrm{mol} / \mathrm{mg}$ ptn per \%PUFA, when compared with the CONT- group. Our results suggest that ingestion of oxidised flaxseed oil increases hepatic MDA concentration and is potentially pro-atherogenic. In addition, the mean MDA value observed in all groups was similar to those reported in other studies that used xenobiotics as oxidative stress inducers. Thus, the diet applied in this study represents an interesting model for further research involving antioxidants.

\section{Key words: Flaxseeds: Oxidation: Malondialdehyde: Mice: Atherosclerosis}

Atherosclerosis is the pathological process that underlies the two major types of CVD: myocardial infarction and stroke ${ }^{(1)}$. Several factors influence the atherosclerotic process in its different stages, including heredity, age, arterial pressure, smoking status, sedentarism and diet ${ }^{(2)}$. Given the risks and ethical concerns, animal models have been applied to investigate the effect of these factors on atherosclerosis progression during life ${ }^{(3)}$. Murine models have been GM to better mimic dyslipidaemia, inflammation and oxidative stress, all conditions present in fatty streaks and atherosclerotic plaque development ${ }^{(4-6)}$. Although genetic engineering of mice is straightforward, causing the animal to carry several customised mutations, most are not available from centralised repositories, making studies less reproducible ${ }^{(7)}$. The use of GM mice normally maintained by repositories, such as LDL-receptor (LDLr) or ApoE knockout (C57BL/6 strain) associated with a high-fat diet, has shown good results in terms of hypertriacylglycerolaemia, hypercholesterolaemia and atherosclerotic disease that progress to myocardial infarction and stroke ${ }^{(3,8,9)}$, but a few changes have been observed in inflammation, and almost none in oxidative stress biomarkers such as hepatic or plasma malondialdehyde (MDA) and antioxidant enzyme activities ${ }^{(10,11)}$. In general, animal protocols involving diabetes induction, exposure to cigarette smoke, administration of xenobiotics, acute exercise, radiation or intermittent hypoxia have caused changes in oxidative biomarkers routinely analysed in clinical studies $^{(6,12-17)}$. A common aspect of most of these models is the use of a high-fat diet, rich in SFA, consisting primarily of lard ${ }^{(18)}$. In fact, this type of diet has been efficient in promoting dyslipidaemia and inflammation ${ }^{(8,19,20)}$.

According to Khan-Merchant et al. ${ }^{(21)}$, dietary oxidised lipids, if incorporated into LDL, could be pro-atherogenic. Indeed, the effect of oxidised lipids consumption on oxidative stress associated with atherosclerosis is controversial. Although some studies have pointed to anti-atherogenic activity ${ }^{(5,22,23)}$, others have suggested exactly the opposite, reporting oxidised fatty

Abbreviations: ALA, $\alpha$-linolenic acid; CONT+, high-fat diet prepared with fresh flaxseed oil + streptozotocin; CONT-, high-fat diet containing fresh flaxseed oil; IS, internal standard; LDLr, LDL-receptor; MDA, malondialdehyde; OXID, high-fat diet prepared with heated flaxseed oil; ptn, portion; TBARS, thiobarbituric acid reactive substances. 
acids consumption as a risk factor for atherosclerosis ${ }^{(24,25)}$. In general, studies that identified anti-atherogenic activity after high doses of oxidised fatty acids and oxidised cholesterol consumption observed impaired cholesterol absorption ${ }^{(5)}$ or activation of PPAR- $\alpha$ in the liver and vasculature, inhibiting monocyte recruitment and smooth vascular cells proliferation and migration ${ }^{(23)}$. Studies that observed atherogenic effects reported that the amount of oxidised lipids in the diet largely determines the levels of oxidised lipids in circulating lipoproteins, increasing inflammation and oxidative stress, accelerating the onset of atherosclerosis lesions formation, mainly when associated with a diet containing a high amount of fat and cholesterol $^{(21,24-27)}$. In a very interesting study, Awada et al. ${ }^{(24)}$ observed that the consumption of oxidised $n-3$ PUFA triggered oxidative stress and inflammation in the upper intestine of mice. In another study, Staprans et al. ${ }^{(25,28)}$ found that an oxidisedcholesterol diet resulted in a $32-38 \%$ increase in fatty streak lesions in $\mathrm{LDLr}^{(--)}$and $\mathrm{ApoE}^{(-/-)}$mice, respectively.

The effect of long-term oxidised fatty acids intake on atherosclerosis progression seems to depend on the type of PUFA. n-3 PUFA intake has been recommended as a supplement (capsules) or replacement for SFA and $n-6$ PUFA in foods and diet. These PUFA are highly susceptible to oxidation. Large amounts of strongly oxidised PUFA are not considered unsafe, because the oxidation products present an unpleasant odour and are poorly absorbed. However, there is no enough information regarding the toxicity of long-term weakly oxidised PUFA. Thus, our objective was to evaluate the effect of long-term consumption of weakly oxidised PUFA from flaxseed oil on in vivo oxidative stress, using an animal model currently applied to investigate atherosclerosis.

\section{Methods and materials}

\section{Material}

Gold flaxseed oil was obtained by applying cold pressure and by filtration from Pazze Ind. Alim. Ltda. Thiobarbituric acid (TBA), TCA, 14\% BF3-methanol, butylated hydroxytoluene (BHT), cumene hydroperoxide and tetraethoxypropane (TEP) 97\% were purchased from Sigma Chemical Co. HPLC-grade solvents were purchased from Merck SA. Milli-Q water was used to prepare all aqueous solutions (Millipore Corp.).

\section{Study design}

First, $50-\mathrm{ml}$ tubes containing $35 \mathrm{ml}$ of flaxseed oil were heated at $100^{\circ} \mathrm{C}$ for $10 \mathrm{~h}$. Preliminary assays proved that this condition $\left(100^{\circ} \mathrm{C} / 10 \mathrm{~h}\right)$ resulted in a weakly oxidised oil as the peroxide value was above the fresh sample $\left(2.67 \mathrm{meq} \mathrm{O}_{2} / \mathrm{kg}\right)$ but below the legislation limit $\left(15 \mathrm{meq} \mathrm{O}_{2} / \mathrm{kg}\right)$. Exposing the oil to direct sunlight or fluorescent light or leaving the oil at room temperature for a longer period of time can also promote its oxidation $^{(29,30)}$. Next, 200 parts per million of tertiary butylhydroquinone (TBHQ) was added and the samples were kept under refrigeration $\left(4^{\circ} \mathrm{C}\right)$ until diet preparation. Oil samples were characterised according to their oxidation level as fresh $(0 \mathrm{~h})$ and heated $(10 \mathrm{~h})$. The high-fat diets were formulated as previously described ${ }^{(31)}$. Flaxseed oil (fresh and heated) was used to replace two-thirds of the lard in the high-fat diet. All diets were extrused. The oxidative markers of the diets were evaluated after extrusion. The mineral mixture of the high-fat diet was modified to make it more similar to 'cafeteria diet"(32). Thus, salt content was doubled (from 74.0 to $148.0 \mathrm{~g} / \mathrm{kg}$ of mineral mixture), and Se was reduced from $0.01025 \mathrm{mg}$ to $0.00512 \mathrm{~g} / \mathrm{kg}$ of the mineral mixture. In addition, Fe was increased from $6.06 \mathrm{~g}$ to $18 \cdot 18 \mathrm{~g} / \mathrm{kg}$ of the mineral mixture. Finally, fibre content was adjusted from $50.0 \mathrm{~g}$ to $100 \cdot 0 \mathrm{~g} / \mathrm{kg}$ of the diet to enable the addition of polyunsaturated oil as a substitute for lard, maintaining the diet in powder form instead of paste.

\section{Animals}

In total, twenty eight male, homozygous, LDLr knockout mice (3 months old) with a C57BL/6 background, weighing 24.61 (sE 0.29) g, were purchased from the Faculty of Pharmaceutical Sciences, University of São Paulo. The mice were housed in plastic cages (five animals per cage) at constant room temperature $\left(22 \pm 2^{\circ} \mathrm{C}\right)$ and relative humidity $(55 \pm 10 \%)$, under a $12 \mathrm{~h}$ light $-12 \mathrm{~h}$ dark cycle. Food and water were available ad libitum. Animals were divided into three groups and fed a high-fat diet, where two-third of the lard used to prepare the diet was substituted by fresh flaxseed oil in the 'negative control' group (CONT-) or by heated flaxseed oil in the OXID group. Another group was fed a high-fat diet prepared with fresh flaxseed oil, but had type 1 diabetes induced by streptozotocin $(180 \mathrm{mg} / \mathrm{kg})$ intraperitoneally without fasting, which was applied at the beginning of the trial, characterising the 'positive control' group (CONT+). The diabetic rat appears to be the most appropriate systemic oxidative stress model ${ }^{(16)}$. Dietary intake was recorded daily, and the animals were weighed individually twice a week. After 3 months, the mice were deprived of food for $8 \mathrm{~h}$ and anaesthetised with isoflurane. Blood samples were collected by heart puncture, immediately centrifuged ( $1600 \boldsymbol{g}$ for $15 \mathrm{~min}$ at $4^{\circ} \mathrm{C}$ ), frozen in liquid $\mathrm{N}_{2}$ and stored $\left(-80^{\circ} \mathrm{C}\right)$ for future analysis. Serum lipoprotein concentrations (total cholesterol - MS 10009010068; LDL-cholesterol - MS 10009010136; HDL-cholesterol - MS 10009010026; TAG - MS 10009010070) and glucose levels (MS 10009010236) were quantified using Labtest Diagnóstica SA. commercial kits for enzymatic colorimetric tests. The liver was excised and weighed. Small pieces of the larger lobe were frozen for analyses. The heart and aorta were collected and fixed in $10 \%$ formol for $24 \mathrm{~h}$. Subsequently, the samples were stored in $70 \%$ ethanol, until stereological analysis. The animal protocol was conducted in accordance with 'National guidelines for the care and use of animals', and was approved by the Ethic Committee for Animal Studies of the Faculty of Pharmaceutical Sciences (Protocol CEUA/FCF 429).

\section{Methods}

Oxidative markers of the flaxseed oil. Lipid hydroperoxide concentrations were determined as previously described ${ }^{(33)}$. The absorbance readings were measured at $510 \mathrm{~nm}$ using a UV-Vis mini 1240 spectrophotometer (Shimadzu Scientific Instrument). The hydroperoxide content was determined using 
a standard curve prepared with known concentrations of cumene hydroperoxide. Concentrations were expressed as meq $\mathrm{O}_{2} / \mathrm{kg}$ of oil. The amount of thiobarbituric acid reactive substances (TBARS) was determined according to previously described procedures ${ }^{(34)}$. Measurements were taken in duplicate and values are expressed as $\mathrm{mg} / \mathrm{kg}$ of oil.

\section{Hexanal by headspace solid-phase microextraction coupled}

with GC-MS. The hexanal content of the samples was determined according to the procedures previously described ${ }^{(35)}$ with some modifications. An emulsion was prepared with $10 \%$ of the oil, and $990 \mu \mathrm{l}$ of this emulsion was added to $10 \mu \mathrm{l}$ of internal standard ( $1 \mu \mathrm{l}$ of $\mathrm{MBIK} / \mathrm{ml}$ in methanol) and hermetically sealed in a $20-\mathrm{ml}$ headspace glass vial with a polypropylene hole cap and PTFE/silicone septa (Supelco). Analysis was carried out in an Agilent 7890A GC-MS (Agilent Technologies). The stationary phase was a ZB-5 MS capillary column （5\% polysilarylene/95\% polydimethylsiloxane; $30 \mathrm{~m} \times 0.32 \mathrm{~mm} ; \quad 1 \mu \mathrm{m}$ film thickness; Phenomenex $^{\circledR}$; Phenomenex Inc.). The ion source and quadrupole temperatures were set at 230 and $150^{\circ} \mathrm{C}$, respectively. Ultra-pure $\mathrm{He}$ was the carrier gas, operated at a constant flow of $1.0 \mathrm{ml} / \mathrm{min}$. The oven temperature was maintained at $40^{\circ} \mathrm{C}$ for $5 \mathrm{~min}$, increased to $100^{\circ} \mathrm{C}$ at $4^{\circ} \mathrm{C} / \mathrm{min}$ and then to $220^{\circ} \mathrm{C}$ at $17^{\circ} \mathrm{C} / \mathrm{min}$; the final temperature was maintained for $10 \mathrm{~min}$. All mass spectra were acquired in electron-impact (EI) mode with an ionisation voltage of $70 \mathrm{eV}$ and a mass range of $35-300 \mathrm{~m} / z$. Total ion content (TIC) and selected-ion monitoring chromatogram were employed as data acquisition mode using the National Institute of Standards and Technology (NIST) library. The following retention times and quantification ions were used: internal standard (IS) $8.7 \mathrm{~min}(43,58$ and $100 \mathrm{~m} / \mathrm{z}$ ) and hexanal $11.7 \mathrm{~min}(44,56$ and $72 \mathrm{~m} / \mathrm{z})$. All quantifications were based on the peak area ratio of the signal of the analyte and the IS signal. A standard curve $(\mu \mathrm{g} / \mathrm{ml}$ hexanal $=39 \cdot 112$ hexanal:IS area ratio; $r 0.995)$ was prepared with five concentrations of hexanal $(0-0.08 \mu \mathrm{g} / \mathrm{ml}$ of fresh emulsion) and the same amount of IS. Results were expressed as $\rho g$ hexanal $/ \mathrm{ml}$ of emulsion; two independent replicates were run per sample.

\section{Fatty acids composition}

Samples were esterified according to the previously described procedure $^{(36)}$. Oil samples $(1.5 \mathrm{mg})$ and tissue homogenates $(10 \mathrm{mg})$ were transferred to tubes containing $1 \mathrm{mg}$ of IS (tricosanoic acid methyl ester (C23:0)), $50 \mu \mathrm{l} 0.5 \%$ BHT and $1 \mathrm{ml} 0.5 \mathrm{M}$-methanolic $\mathrm{NaOH}$. Fatty acids quantification was carried out using a GC equipped with a G3243A MS detector (Agilent 7890A GC System; Agilent Technologies Inc.). A fused silica capillary column (J\&W DB-23 Agilent 122-236; $60 \mathrm{~m} \times 250 \mathrm{~mm}$ inner diameter) was used to inject $1 \mu \mathrm{l}$ of the sample. High-purity He was used as the carrier gas at a flow rate of $1.3 \mathrm{ml} / \mathrm{min}$ with a split injection of $50: 1$. The oven temperature was programmed from 80 to $175^{\circ} \mathrm{C}$ at a rate of $5^{\circ} \mathrm{C} / \mathrm{min}$, followed by another gradient of $3^{\circ} \mathrm{C} / \mathrm{min}$ to $230^{\circ} \mathrm{C}$, which was maintained for $5 \mathrm{~min}$. The GC inlet and transfer line temperatures were 250 and $280^{\circ} \mathrm{C}$, respectively. GC-MS was performed using $70 \mathrm{eV}$ EI in scan acquisition and quantified by TIC. The fatty acids were identified by NIST and by comparing the retention time with those of four purified standard mixtures of fatty acid methyl esters (4-7801; 47085-U; 49453-U and 47885-U; Sigma Chemical Co.). All mass spectra were acquired over an $\mathrm{m} / \mathrm{z}$ range of $40-500$. Samples were analysed in triplicate and results are expressed as percentage of fatty acids in oil or $\mathrm{mg} / 100 \mathrm{mg}$ of hepatic tissue.

\section{Oxidative stress biomarkers}

The assessment of aortic wall thickness and lumen. The stereological parameters were estimated using Visiopharm (version 4.6.3.857) stereologic NEWCAST ${ }^{\mathrm{TM}}$ software. The ascending aorta was isolated from the heart at the height of the aortic sinus and at the beginning of the aortic arch. Each ascending aorta was weighed and measured by a digital caliper. Subsequently, samples were placed in sucrose (7\%) overnight, frozen and sectioned in a cryostat Leica (Leica Imaging Systems) at a thickness of $10 \mu \mathrm{m}$. The Cavalieri's principle was used to estimate the volume of the aortic lumen and wall compartments ${ }^{(37,38)}$.

\section{Determination of malondialdehyde concentration in liver} homogenates. MDA concentration was determined by reversephase HPLC, following the protocol previously described ${ }^{(39)}$, with modifications. Liver homogenates $(0.05 \mathrm{ml})$ were mixed with $12.5 \mu \mathrm{l}$ of $0.2 \% \mathrm{BHT}$ and $6.25 \mu \mathrm{l}$ of $10 \mathrm{~N} \mathrm{NaOH}$. About $20 \mu \mathrm{l}$ of the TBA-MDA conjugate derivative was injected for HPLC (Agilent Technologies 1200 Series) in a Phenomenex reverse-phase C18 analytical column $(250 \mathrm{~mm} \times 4.6 \mathrm{~mm} ; 5 \mathrm{~mm}$; Phenomenex) with an LC8-D8 pre-column (Phenomenex AJ01287) and was fluorometrically quantified at an excitation of $515 \mathrm{~nm}$ and emission of $553 \mathrm{~nm}$. The HPLC pump delivered the isocratic mobile phase: $60 \%$ PBS (10 mmol, pH 7·1)+40\% methanol at a flow rate of $1.0 \mathrm{ml} / \mathrm{min}$. A standard curve was prepared using TEP. The results are expressed as $\eta$ mol MDA/ mg protein. According to Frankel ${ }^{(30)}$, precursors of MDA are endoperoxides produced as secondary products of PUFA containing three or more double bonds. Thus, considering that SFA and MUFA are not precursors of MDA, and that the amount of PUFA observed in the liver was different among the groups, the results were also expressed as $\mu \mathrm{mol} / \mathrm{mg}$ protein per \%PUFA.

Antioxidant enzyme activities in liver homogenates. Superoxide dismutase (SOD) activity was determined according to the previously described procedure ${ }^{(40)}$. Liver homogenates containing $0.024 \mu \mathrm{g} / \mu \mathrm{l}$ of protein $(25 \mu \mathrm{l})$ were placed into a microplate with $200 \mu \mathrm{l}$ of freshly prepared $0.1 \mathrm{mm-EDTA}$, $62 \mu \mathrm{m}-$ Nitrotetrazolium blue chloride (NBT) and $98 \mu \mathrm{m}-\mathrm{NADH}$ in $50 \mathrm{~mm}-\mathrm{PBS}(\mathrm{pH} 7 \cdot 4$ ). The reaction was initiated with the addition of $25 \mu \mathrm{l}$ of freshly prepared $33 \mu \mathrm{m}$-phenazine methosulphate in $50 \mathrm{~mm}$-PBS ( $\mathrm{pH} 7 \cdot 4$ ) containing $0 \cdot 1 \mathrm{mm-EDTA}$. Absorbance at $560 \mathrm{~nm}$ was continuously monitored over $5 \mathrm{~min}$ as an index of NBT reduction. A standard curve was prepared using SOD (Sigma Chemical Co.) (0.173-2.77 U/mg portion (ptn)). Glutathione peroxidase (GPx) activity was determined according to a previously described procedure ${ }^{(41)}$, with modifications. In brief, $30 \mu \mathrm{l}$ of the homogenate (with $25 \mu \mathrm{g} / \mu \mathrm{l} \mathrm{ptn}$ ) was incubated at $37^{\circ} \mathrm{C}$ for $5 \mathrm{~min}$ with $125 \mu \mathrm{l}$ of $0.1 \mathrm{~m}$-PBS and $1 \mathrm{~mm}-$ EDTA ( $\mathrm{pH} 7 \cdot 4$ ), $5 \mu \mathrm{l}$ of freshly prepared $0.08 \mathrm{M}-\mathrm{GSH}$ and $5 \mu \mathrm{l}$ of freshly prepared glutathione reductase (GR) (9.6 U). Next, $30 \mu \mathrm{l}$ 
of $4 \mathrm{mg} / \mathrm{ml} \mathrm{NADPH}$ and $5 \mu \mathrm{l}$ of $0.46 \%$ TBHQ were added to the reaction. Absorbance at $340 \mathrm{~nm}$ was continuously monitored over 4 min at $37^{\circ} \mathrm{C}$. A standard curve was prepared using GPx enzyme (Sigma Chemical Co.) (2.08-25 U/mg ptn). GR activity was determined as previously described ${ }^{(42)}$, with modifications. Liver homogenate containing $4.0 \mu \mathrm{g} / \mu \mathrm{l}$ of protein $(20 \mu \mathrm{l})$ was incubated for $5 \mathrm{~min}$ at $37^{\circ} \mathrm{C}$ with $180 \mu \mathrm{l}$ of reaction medium containing $2 \mathrm{ml}$ of $0 \cdot 1 \mathrm{~m}$ PBS with $1 \mathrm{~mm}$-EDTA (pH 7), $1.5 \mathrm{ml}$ of $0.005 \mathrm{~m}$ EDTA, $1.5 \mathrm{ml}$ of milli-Q water, $10 \mathrm{mg}$ of glutathione disulphide and $2 \mathrm{mg}$ of NADPH. Absorbance at $340 \mathrm{~nm}$ was continuously monitored. A standard curve was prepared using GR enzyme (Sigma Chemical Co.) (0.003-0.25 U/mg ptn).
All enzymatic assays were performed using a plate reader (Multi-Detection microplate reader; Synergy - BioTek) integrated with Gen 5 software. Samples were analysed in triplicate.

Liver steatosis analysis. Liver tissue samples were fixed in $10 \%$ formalin for $24 \mathrm{~h}$ and then embedded in paraffin wax. The samples were cut into $5-\mu \mathrm{m}$ sections and stained with haematoxylin-eosin to evaluate steatosis and inflammation. Steatosis, hepatocellular ballooning and lobular inflammation were determined histopathologically and graded as described elsewhere ${ }^{(43)}$. The degree of steatosis was graded using the following four-point scale: grade 0 , steatosis involving $<5 \%$ of
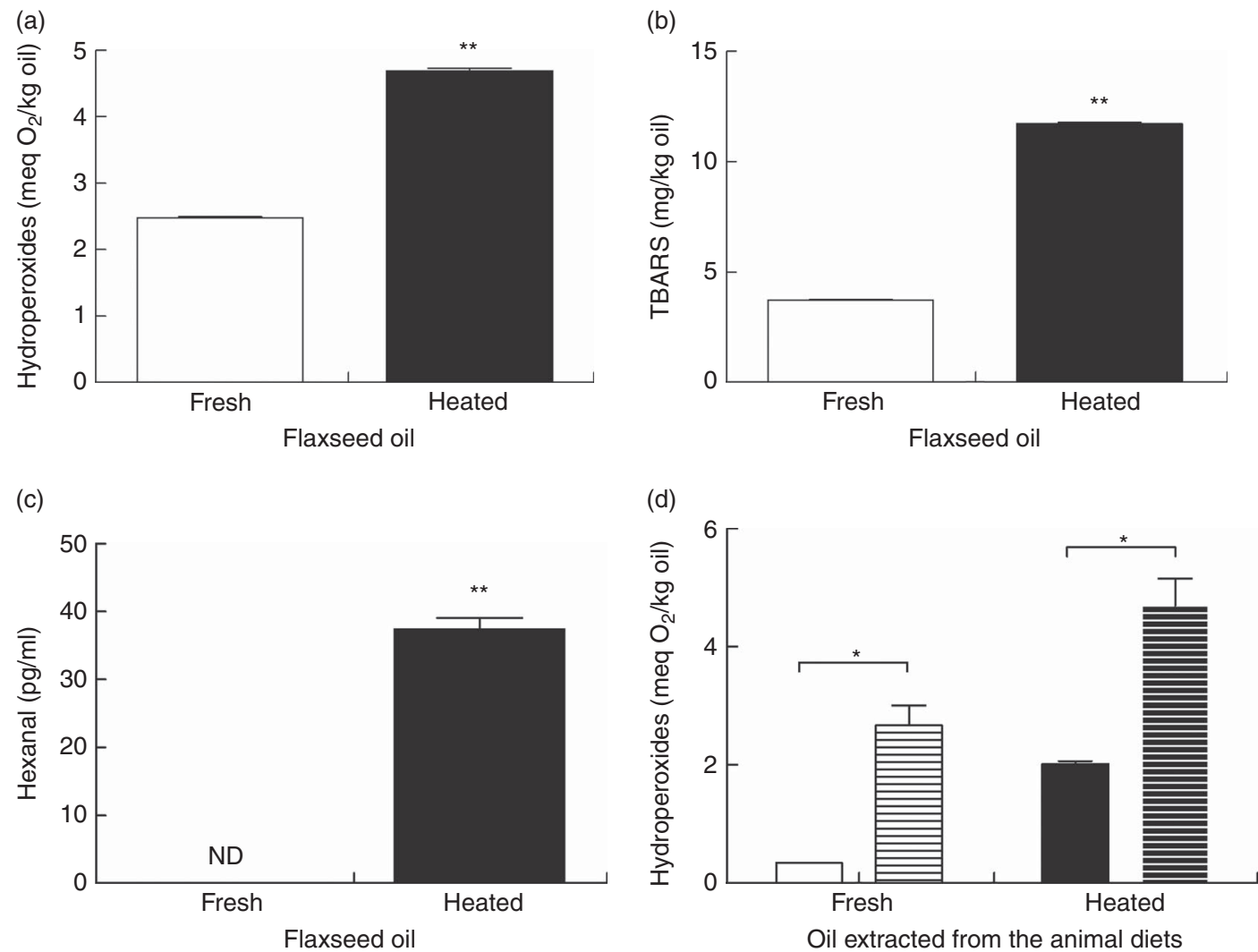

(e)

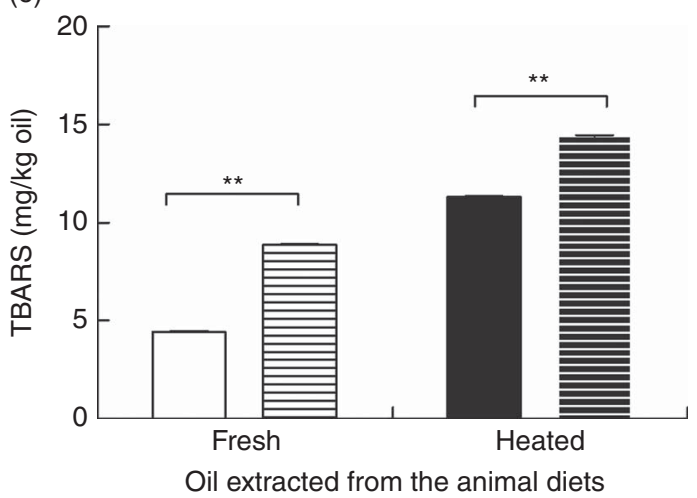

Fig. 1. Oxidative markers evaluated in fresh and heated $\left(100^{\circ} \mathrm{C} / 10 \mathrm{~h}\right.$ ) flaxseed oil samples: (a) hydroperoxides (meq $\mathrm{O}_{2} / \mathrm{kg}$ oil); (b) thiobarbituric acid reactive substances (TBARS) ( $\mathrm{mg} / \mathrm{kg}$ oil) and (c) hexanal $(\mathrm{pg} / \mathrm{ml}$ ) concentrations, and in the oil extracted from the diets before and after extrusion: hydroperoxides (d) and TBARS (e) concentrations. Values are means $(n 2)$, with standard errors represented by vertical bars. ${ }^{*} P<0.05 ;{ }^{* *} P<0.01$. $\square$, Before; 具, after. 
hepatocytes; grade 1, steatosis involving up to $33 \%$ of hepatocytes; grade 2 , steatosis involving $33-66 \%$ of hepatocytes; and grade 3 , steatosis involving $>66 \%$ of hepatocytes. Lobular inflammation was also graded on a four-point scale: grade 0 , no foci; grade 1 , fewer than two foci per $20 \times$ field; grade 2 , two to four foci per $20 \times$ field; and grade 3 , more than four foci per $20 \times$ field. Hepatocyte ballooning was graded on a three-point scale: 0 , none; 1 , a few balloon cells; and 2, any/prominent balloon cells. For non-alcoholic fatty liver disease activity score (NAS), features of steatosis, lobular inflammation and hepatocyte ballooning were combined, and the range of values were from 0 to 8 .

Statistical analysis. Values are expressed as mean values with their standard errors. Variance homogeneity was previously evaluated for all variables by Hartley's test, and data were submitted to a Box-Cox transformation when necessary. Oxidative markers of the fresh and heated flaxseed oils were compared by $t$ test for independent samples, whereas the diet extrusion effect was treated by $t$ test for dependent samples. One-way ANOVA or Kruskal-Wallis ANOVA followed by the post hoc Tukey's test or multiple comparisons of mean ranks was used to evaluate the differences among the three experimental groups. Non-parametric $\chi^{2}$ test was applied to compare steatosis levels and NAS index. Significance was set at $P$ values $<0 \cdot 05$. All the analyses were performed using STATISTICA version 9.0 (StatSoft Inc.).

\section{Results}

The oxidative markers of the flaxseed oil samples used to prepare the animals' diet are shown in Fig. 1. Flaxseed oil heated at $100^{\circ} \mathrm{C}$ for $10 \mathrm{~h}$ exhibited a higher concentration of hydroperoxides (Fig. 1(a)), TBARS (Fig. 1(b)) and hexanal (Fig. 1(c)) than fresh flaxseed oil. After mixture, all animal diets were extrused. Given that the extrusion process involves additional heat treatment, the oxidative markers were evaluated in the oils extracted from the diets before and after extrusion. Concentrations of hydroperoxides (Fig. 1(d)) and TBARS (Fig. 1(e)) increased after extrusion. However, this increase was proportional to the oils extracted from both diets. Chemical composition, fatty acids content and oxidative markers in the two diets applied in this study are shown in Table 1. No alterations were observed in nutrients and just a few changes were found in the fatty acids profile. As expected, the OXID diet showed higher hydroperoxides and TBARS values than the CONT diet.

Table 2 presents the metabolic parameters observed in the animals according to the experimental groups. No differences were observed between the three groups, except for the lower body weight gain/diet intake found in the CONT+ group. In relation to tissue weight, CONT+ exhibited the highest value for hepatic tissue and lowest for adipose tissue, compared with the other two groups. However, CONT+ did not show higher glucose concentration $(13.61 \mathrm{mmol} / \mathrm{l})$ compared with the others

Table 1. Chemical composition, fatty acid content and oxidative markers of the diets containing fresh and oxidised flaxseed oils (Mean values with their standard errors)

\begin{tabular}{|c|c|c|c|c|c|}
\hline & \multicolumn{5}{|c|}{ High-fat diets* } \\
\hline & \multicolumn{2}{|c|}{ CONT† } & \multicolumn{2}{|c|}{ OXID } & \multirow[b]{2}{*}{$P \ddagger$} \\
\hline & Mean & $\mathrm{SE}$ & Mean & $\mathrm{SE}$ & \\
\hline \multicolumn{6}{|l|}{ Nutrients $(\mathrm{g} / 100 \mathrm{~g})$} \\
\hline Moisture & 6.52 & 0.11 & 6.71 & 0.03 & 0.169 \\
\hline Ashes & 3.43 & 0.11 & $3 \cdot 20$ & 0.02 & 0.105 \\
\hline Lipids & $30 \cdot 32$ & 0.20 & 30.87 & 0.40 & 0.287 \\
\hline Proteins & $16 \cdot 79$ & 0.30 & $16 \cdot 62$ & 0.03 & 0.596 \\
\hline Carbohydrates & 42.94 & 0.57 & $42 \cdot 60$ & 0.45 & 0.668 \\
\hline Energy (kJ/100 g) & 2141.41 & 1.59 & $2153 \cdot 71$ & $8 \cdot 16$ & 0.214 \\
\hline Energy $(\mathrm{kcal} / 100 \mathrm{~g})$ & $511 \cdot 81$ & 0.38 & 514.75 & 1.95 & 0.214 \\
\hline \multicolumn{6}{|l|}{ Major fatty acids (\%)§ } \\
\hline C14:0 & 0.49 & 0.01 & 0.50 & 0.01 & 0.969 \\
\hline C16:0 & 18.67 & 0.01 & 18.85 & 0.01 & 0.156 \\
\hline $\mathrm{C} 16: 1$ & 0.60 & 0.02 & 0.59 & 0.03 & 0.821 \\
\hline C18:0 & $11 \cdot 70$ & 0.09 & 11.04 & 0.45 & 0.152 \\
\hline C18:1n-9 cis & 24.71 & 0.02 & $25 \cdot 79$ & 0.37 & 0.018 \\
\hline C18: $1 n-9$ trans & 1.21 & 0.06 & $1 \cdot 11$ & 0.02 & 0.239 \\
\hline $\mathrm{C} 18: 2 n-6$ & $13 \cdot 17$ & 0.03 & $14 \cdot 86$ & 0.14 & $<0.001$ \\
\hline C18:3n-3 & 29.94 & 0.14 & $28 \cdot 76$ & 0.55 & 0.061 \\
\hline \multicolumn{6}{|l|}{ Oxidative markers } \\
\hline $\mathrm{LOOH}\left(\right.$ meq $\mathrm{O}_{2} / \mathrm{kg}$ oil) $\S$ & $2 \cdot 67$ & 0.24 & 4.70 & 0.32 & 0.037 \\
\hline TBARS (mg/l oil)§ & 8.85 & 0.06 & 14.42 & 0.06 & $<0.001$ \\
\hline \multicolumn{6}{|c|}{$\begin{array}{l}\text { CONT, control; OXID, high-fat diet prepared with heated flaxseed oil; LOOH, lipid hydroperoxide; TBARS, thiobarbituric acid reactive substances. } \\
\text { * High-fat diet (g/kg) was composed of starch (195.5), casein (151.20), dextrin (100.0), sucrose (100.0), lard (100.0), flaxseed oil }(200.0) \text {, fibre }(100.0) \text {, } \\
\text { mineral mixture (AIN-93M-MX; } 37.8) \text {, vitamin mixture (AIN-93M-VX; } 10.8) \text {, L-cystine (1.94), choline bitartarate }(2.7) \text { and tertiary butylhydroquinone } \\
\text { (0.06). In the mineral mix, salt content was doubled (from } 74.0 \text { to } 148.0 \mathrm{~g} / \mathrm{kg} \text { of mineral mixture), Se was reduced from } 0.0125 \mathrm{~g} \text { to } 0.00512 \mathrm{~g} / \mathrm{kg} \text { and Fe } \\
\text { was increased from } 6.06 \mathrm{~g} \text { to } 18.18 \mathrm{~g} / \mathrm{kg} \text {. }\end{array}$} \\
\hline
\end{tabular}


Table 2. Diet intake, body weight, blood lipid profile, tissue weight and hepatic fatty acids measured in the animals (Mean values with their standard errors)

\begin{tabular}{|c|c|c|c|c|c|c|c|}
\hline & \multicolumn{7}{|c|}{ Experimental groups } \\
\hline & \multicolumn{2}{|c|}{ CONT- } & \multicolumn{2}{|c|}{ OXID } & \multicolumn{2}{|c|}{ CONT+ } & \multirow[b]{2}{*}{$P^{\star}$} \\
\hline & Mean & SE & Mean & SE & Mean & SE & \\
\hline Diet intake (g/d) & 0.86 & 0.00 & 0.90 & 0.09 & 0.88 & 0.07 & 0.924 \\
\hline Energy intake (kJ/d) & $18 \cdot 37$ & 0.04 & $19 \cdot 29$ & $2 \cdot 05$ & $18 \cdot 87$ & 1.51 & 0.907 \\
\hline Energy intake (kcal/d) & $4 \cdot 39$ & 0.01 & $4 \cdot 61$ & 0.49 & 4.51 & 0.36 & 0.907 \\
\hline Initial body weight (g) & $24 \cdot 20$ & 0.54 & $24 \cdot 50$ & 0.44 & $25 \cdot 27$ & 0.51 & 0.439 \\
\hline Final body weight (g) & $28 \cdot 68$ & $1 \cdot 25$ & $28 \cdot 55$ & 0.52 & $25 \cdot 73$ & 0.79 & 0.063 \\
\hline Body weight gain/diet intake & $5 \cdot 21$ & $1 \cdot 32^{\mathrm{a}}$ & 4.51 & $0.64^{\mathrm{a}}$ & 0.52 & $0.60^{\mathrm{b}}$ & 0.006 \\
\hline \multicolumn{8}{|l|}{ Blood lipid profile } \\
\hline Total cholesterol (mmol/l) & $7 \cdot 79$ & 0.26 & $7 \cdot 55$ & 0.59 & $9 \cdot 10$ & 1.60 & 0.608 \\
\hline HDL-cholesterol (mmol/l) & $1 \cdot 88$ & 0.05 & 1.87 & $0 \cdot 15$ & 2.05 & $0 \cdot 15$ & 0.620 \\
\hline LDL-cholesterol (mmol/l) & 2.66 & 0.11 & 2.46 & $0 \cdot 22$ & 2.90 & 0.46 & 0.661 \\
\hline VLDL-cholesterol (mmol/l) & $3 \cdot 24$ & 0.14 & 3.29 & $0 \cdot 29$ & $4 \cdot 16$ & 1.07 & 0.545 \\
\hline TAG $(\mathrm{mmol} / \mathrm{l})$ & 0.84 & 0.04 & 0.90 & $0 \cdot 10$ & 0.75 & $0 \cdot 16$ & $0 \cdot 271$ \\
\hline Glucose (mmol/l) & $10 \cdot 90$ & 0.57 & 11.03 & $0 \cdot 86$ & $13 \cdot 61$ & 1.95 & $0 \cdot 706$ \\
\hline \multicolumn{8}{|l|}{ Relative tissue weight } \\
\hline Liver (\%) & $3 \cdot 22$ & $0.13^{\mathrm{a}}$ & 3.08 & $0 \cdot 13^{a}$ & 3.90 & $0.26^{b}$ & 0.007 \\
\hline Abdominal adipose (\%) & 1.96 & $0.26^{\mathrm{a}}$ & 1.84 & $0 \cdot 13^{\mathrm{a}}$ & $1 \cdot 21$ & $0 \cdot 17^{b}$ & 0.022 \\
\hline Retro-epididymal adipose (\%) & 2.91 & $0.46^{\mathrm{a}}$ & 2.44 & $0 \cdot 25^{\mathrm{a}}$ & 1.44 & $0 \cdot 17^{b}$ & 0.015 \\
\hline Retro-peritoneal adipose (\%) & 0.88 & $0 \cdot 15^{\mathrm{a}}$ & 0.86 & $0 \cdot 11^{a}$ & 0.36 & $0.05^{b}$ & 0.037 \\
\hline \multicolumn{8}{|l|}{ Hepatic fatty acids (mg/g tissue) } \\
\hline C16:0 & $16 \cdot 28$ & $0.80^{\mathrm{a}}$ & $13 \cdot 79$ & $0.48^{b}$ & $13 \cdot 40$ & $0.63^{b}$ & 0.006 \\
\hline C16:1 & $9 \cdot 66$ & 0.36 & 9.00 & 0.27 & 8.96 & $0 \cdot 29$ & $0 \cdot 208$ \\
\hline C18:0 & 0.76 & 0.05 & 0.66 & 0.05 & 0.48 & 0.03 & 0.075 \\
\hline C18: $1 n-9$ cis & $12 \cdot 97$ & $1 \cdot 32^{\mathrm{a}}$ & $8 \cdot 51$ & $0.64^{b}$ & $8 \cdot 60$ & $0 \cdot 86^{b}$ & 0.007 \\
\hline C18: $1 n-9$ trans & $0 \cdot 75$ & 0.05 & \multicolumn{2}{|c|}{-} & \multicolumn{2}{|c|}{-} & - \\
\hline C18: $2 n-6$ cis & $9 \cdot 72$ & $0.76^{\mathrm{a}}$ & $7 \cdot 43$ & $0.58^{b}$ & $6 \cdot 23$ & $0.58^{b}$ & 0.002 \\
\hline C18:3n-3 & $7 \cdot 24$ & $0.93^{a}$ & 4.45 & $0.53^{b}$ & 4.50 & $0.58^{b}$ & 0.041 \\
\hline C20 : $4 n-6$ & 1.83 & $0.10^{\mathrm{a}}$ & 1.53 & $0.09^{b}$ & 1.34 & $0.06^{b}$ & 0.002 \\
\hline $\mathrm{C} 20: 5 n-3$ & 1.52 & $0.09^{a}$ & $1 \cdot 16$ & $0 \cdot 13^{b}$ & 1.03 & $0.04^{b}$ & 0.001 \\
\hline C22: $6 n-3$ & 2.60 & $0 \cdot 26$ & $2 \cdot 19$ & $0 \cdot 12$ & 2.04 & 0.11 & 0.076 \\
\hline
\end{tabular}

CONT-, high-fat diet containing fresh flaxseed oil; OXID, high-fat diet prepared with heated flaxseed oil; CONT+, high-fat diet prepared with fresh flaxseed oil + streptozotocin. ${ }^{\mathrm{a}, \mathrm{b}}$ Mean values within a row with unlike superscript letters were significantly different $(P<0.05)$.

* Probability values obtained by ANOVA or Kruskal-Wallis ANOVA.

$(10 \cdot 96 \mathrm{mmol} / \mathrm{l})$. OXID and CONT+ groups displayed a reduced amount of all PUFA except DHA, when compared with the CONT- group

Fig. 2 presents histopatological microphotographs of the hepatic tissue. All three groups received a high-fat diet, and no intergroup differences were recorded in steatosis or the NAS index, as observed in Fig. 2(a-c).

Oxidative biomarkers measured in liver and plasma are shown in Fig. 3. No differences were observed in MDA concentration, expressed as $\eta \mathrm{mol} / \mathrm{mg}$ ptn (Fig. 3(a)) in the liver homogenate. However, when concentration was adjusted for the amount of PUFA and expressed as $\mu \mathrm{mol} / \mathrm{mg}$ ptn per \%PUFA (Fig. 3(b)), the OXID and CONT+ groups showed a higher concentration than the CONT- group. No changes were observed in plasma MDA concentration (Fig. 3(c)) or in antioxidant enzyme activities such as SOD (Fig. 3(d)), GPx (Fig. 3(e)) and GR (Fig. 3(f)). Fig. 4(a-c) shows a representative image of the aorta obtained from the three experimental groups (Fig. 4(a): CONT-; Fig. 4(b): OXID and Fig. 4(c): CONT+), whereas aorta thickness, lumen and total diameter are shown in Fig. $4(\mathrm{~d}-\mathrm{f})$, respectively. Samples of the aorta from the OXID group exhibited higher thickness, lumen and total diameter compared with the samples obtained from the other two groups, characterising an isolated effect of PUFA oxidation products on these parameters.

\section{Discussion}

On the basis of the hypothesis that PUFA contribute to oxidative stress, whereas SFA are protective ${ }^{(44,45)}$, our results confirmed that a long-term intake of weakly oxidised flaxseed oil containing about $44 \% \alpha$-linolenic acid (ALA) and $15 \%$ linoleic acid (LNA), as part of a high-fat diet, could increase oxidative stress in the liver of $\mathrm{LDLr}^{(--)}$mice. The group fed oxidised flaxseed oil (OXID) showed a similar MDA concentration in the liver (0.25 (sE 0.05) $\mathrm{mmol} / \mathrm{mg}$ ptn per \% PUFA) to that observed in diabetic mice (CONT+) $(0.27$ (SE 0.05$) \mathrm{mmol} / \mathrm{mg}$ ptn per $\%$ PUFA), both higher than the value found in the group that received the high-fat diet prepared with fresh flaxseed oil (CONT-) (0.13 (se 0.01) mmol/mg ptn per \% PUFA). In studies carried out with rodents and humans, it was found that oxidised lipids in the diet, including fatty acids and cholesterol, are absorbed and packed into chylomicrons ${ }^{(27,46)}$. In rodents, oxidised lipids are delivered to the liver, incorporated into serum lipoproteins and transported into VLDL, which is secreted into the circulation ${ }^{(25)}$. In our study, some of the fatty acids 


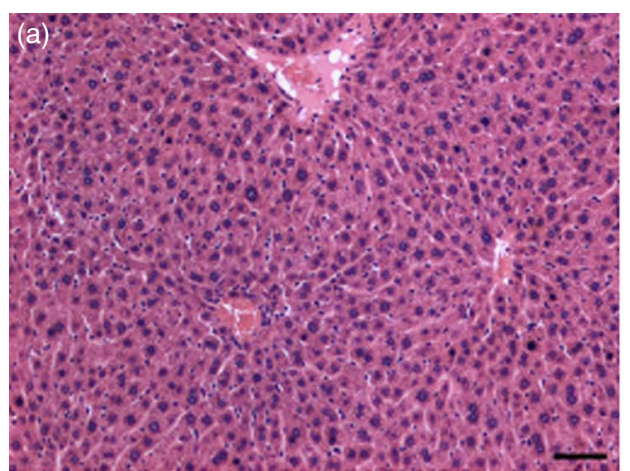

CONT-

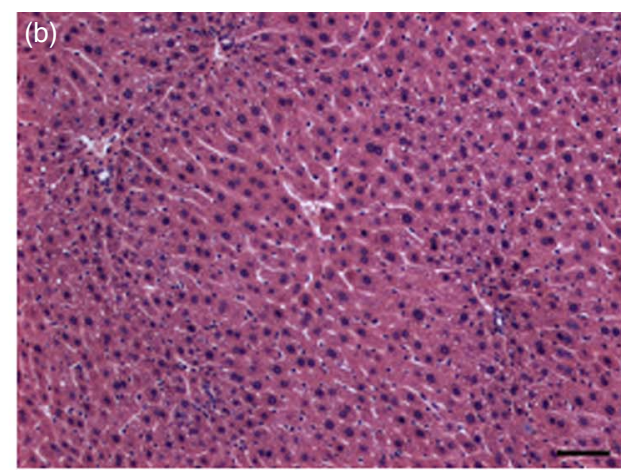

OXID

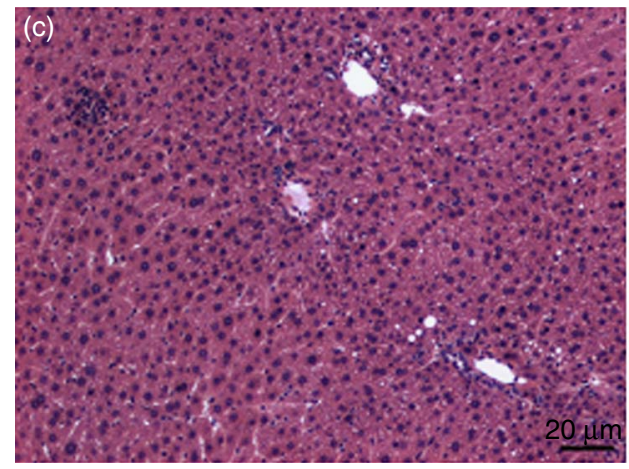

CONT+

Fig. 2. Liver samples were stained with haematoxylin-eosin, the magnification is $100 \times$ and the scale bars represent $20 \mu \mathrm{m}$. The liver of mice fed a high-fat diet prepared with fresh flaxseed oil (CONT-) (a), a high-fat diet prepared with heated flaxseed oil (OXID) (b) and fed a high-fat diet prepared with fresh flaxseed oil + streptozotocin (CONT+) (c) showed similar liver steatosis.

present in the blood lipid profile of the OXID animals were already oxidised, increasing the concentration of hepatic MDA and likely other $n$-alkanals. These compounds form adducts with lysine $\varepsilon$-amino residues in the apo B, modifying the LDL molecules and increasing the expression of CD36 scavenger receptors, which favours modified LDL uptake by macrophages, leading to an increase in aortic lesions ${ }^{(47-50)}$. It has been reported that the intake of oxidised PUFA affects the antioxidant defence system ${ }^{(24)}$. Compounds produced from thermally induced autoxidation of PUFA are metabolised via addition of GSH in the liver by gluthatione-S-transferase and excreted as mercapturate conjugates in the urine ${ }^{(14,47,51)}$. Thus, depletion of intracellular GSH via 'Michael addition' can also contribute to raising oxidative stress. In addition, minor components in the flaxseed oil and their decomposition during heating could be contributing to the effects observed in the animals. However, more studies must be carried out aiming to evaluate the specific contribution of each minor component to oxidative stress.

On the other hand, the results observed in the CONT+ group can be explained by the fact that hyperglycaemia contributes to oxidative stress through different mechanisms, including increased polyol pathway flux, increased intracellular formation of advanced end products, activation of protein kinase $\mathrm{C}$ or over-production of the superoxide anion by the mitochondrial electron transport chain ${ }^{(52)}$.

Except for MDA concentration measured in the liver, no changes were observed in the other biomarkers evaluated in our model. Some hypotheses can be raised to explain this result. First, the flaxseed oil was submitted to low oxidation ( 4.69 meq $\mathrm{O}_{2} / \mathrm{kg}$ ), considering 15.00 meq $\mathrm{O}_{2} / \mathrm{kg}$ as the legal limit for commercial food-grade oils ${ }^{(53)}$ Staprans et al. ${ }^{(26)}$ supplemented female Sprague-Dawley rats by gastric intubation with oxidised maize oil, containing about three times more peroxides than the flaxseed oil used in our study. The authors reported an increase in serum peroxides and TBARS compared with a group fed a lipid-free sucrose diet. Khan-Merchant et al. ${ }^{(21)}$ observed an increase in aortic lesion areas of more than $100 \%$ in LDLr $^{(-/)}$mice fed $5.6 \mathrm{mg}$ of oxidised LNA by gavage associated with a high-fat diet, whereas the amount estimated in our study was only $2.9 \mathrm{mg}$ of oxidised LNA + ALA. We chose a low oxidation level in order to mimic the realistic values found in foods considered safe for human consumption and also to avoid diet rejection by the animals, owing to the strong odour characteristic of the secondary products of PUFA oxidation ${ }^{(54)}$, as oral supplementation was used in our study instead of gastric intubation. It has been reported that lipid hydroperoxides are acutely toxic to rodents, but their effect tends to be less severe after oral administration, because of their reduced absorption across the enterocytes ${ }^{(47)}$. Thus, the low level of oil oxidation associated with reduced absorption of its oxidation products could have contributed to the lack of significant alterations in the biomarkers, except for hepatic MDA. Our second hypothesis is based on the type of oxidative marker selected in different studies. Short-chain aldehydes generated from lipid peroxidation are usually classified into 2-alkenals 
(a)

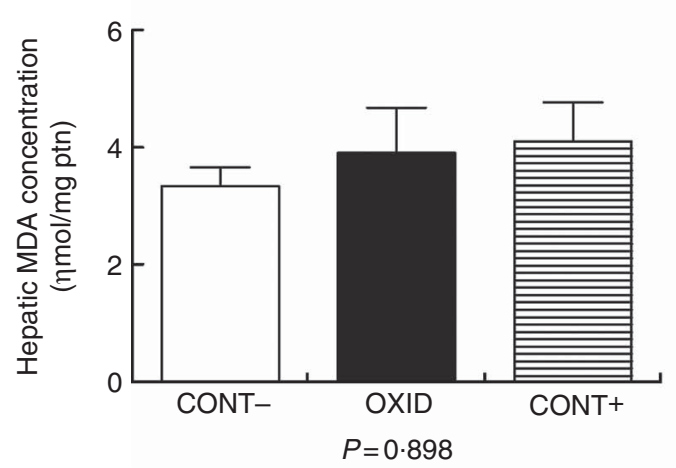

(c)

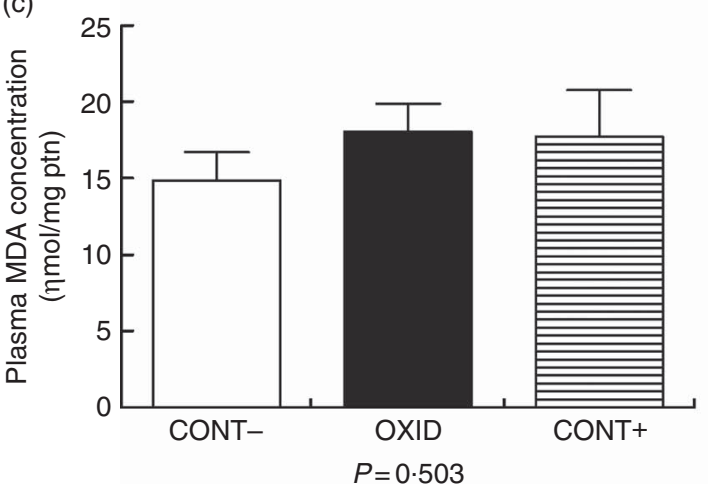

(e)

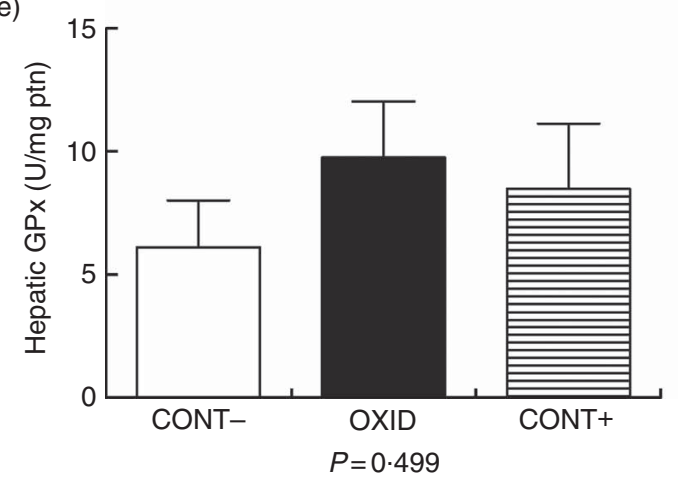

(b)

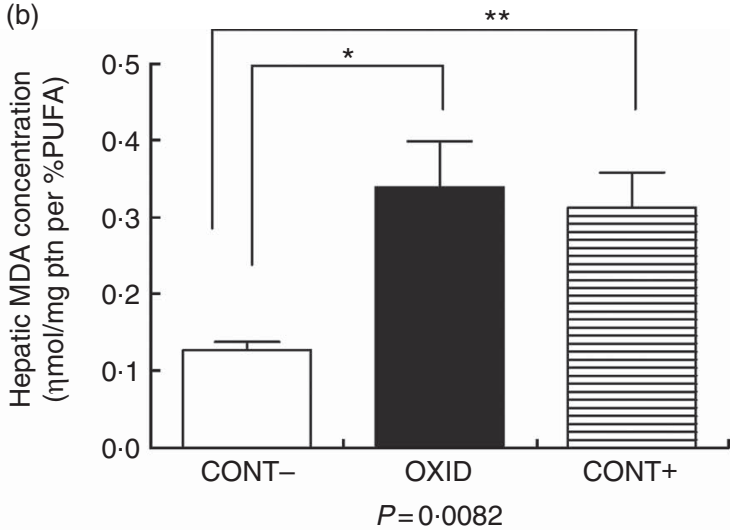

(d)

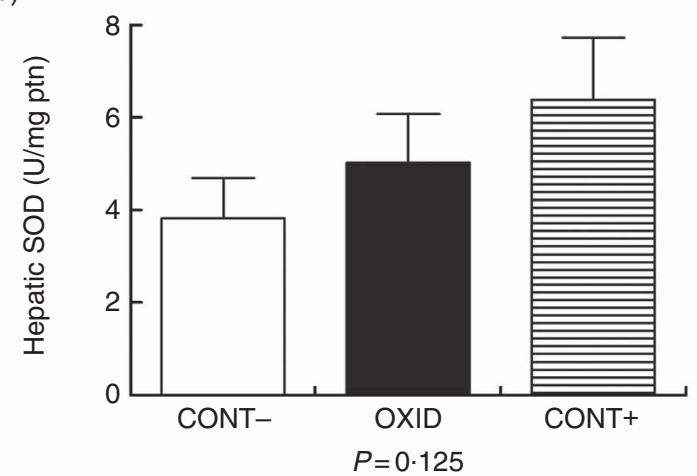

(f)

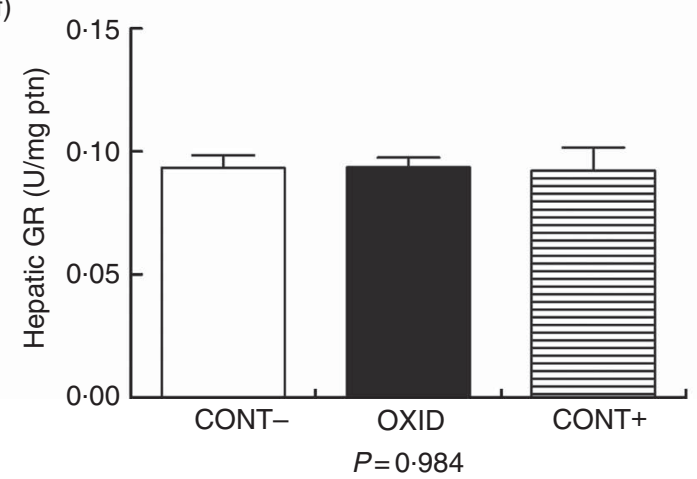

Fig. 3. Hepatic malondialdehyde (MDA) content expressed as $\eta \mathrm{mol} / \mathrm{mg}$ portion (ptn) (a) and $\mu \mathrm{mol} / \mathrm{mg}$ ptn per \%PUFA (b), plasma MDA content expressed as $\eta \mathrm{mol} / \mathrm{mg}$ ptn (c) and enzymatic activity expressed as $\mathrm{U} / \mathrm{mg}$ ptn for superoxide dismutase (SOD) (d), glutathione peroxidase (GPx) (e) and glutathione reductase (GR) (f). Values are means $(n 10)$, with standard errors represented by vertical bars. ${ }^{*} P<0.05 ;{ }^{* *} P<0.01$. CONT-, high-fat diet prepared with fresh flaxseed oil; OXID, high-fat diet prepared with heated flaxseed oil; CONT+, high-fat diet prepared with fresh flaxseed oil + streptozotocin.

(e.g. acrolein), 4-hydroxy-2-alkenals (e.g. 4-hydroxy-2-nonenal (HNE), 4-hydroxy-2-hexenal (HHE)) and ketoaldehydes (e.g. MDA). Although HNE is the major aldehyde produced during $n-6$ fatty acids oxidation, and HHE is characteristic of $n-3$ fatty acids oxidation, MDA is the most abundant specific lipid-peroxidation aldehyde capable of forming adducts with lysine residues $^{(49,51)}$. For this reason, MDA was the biomarker chosen in our study. However, 4-HHE, propanol, F3-isoprostanes, F4-neuroprostanes and their isomers are more specific products from $n-3$ fatty acid oxidation ${ }^{(30,55,56)}$. The major PUFA present in the flaxseed oil is $n-3$ ALA, accounting for about $44 \%$ of the total. Therefore, 4-HHE, propanol and F3-isoprotanes quantification could be applied to better complement MDA analysis in future studies. The third hypothesis is that in the diet offered to all three groups, $\mathrm{Fe}$ and salt contents were increased while Se was decreased, in order to promote a higher response in terms of oxidative stress and also mimic Western diets. Several experiments support the idea that oxidised $\mathrm{Hb}$ and $\mathrm{Fe}$ overload enhance lipid peroxidation in the liver ${ }^{(45,49,57)}$. In addition to Fe, Se is a cofactor for GPx activity ${ }^{(58)}$, and the diet of all groups exhibited reduced Se content, contributing to increased oxidative stress, irrespective of the presence of oxidised lipids. Finally, Yin et al. ${ }^{(59)}$ reported that the same oxidation products generated in vitro by free-radical mechanisms can be 
(a)

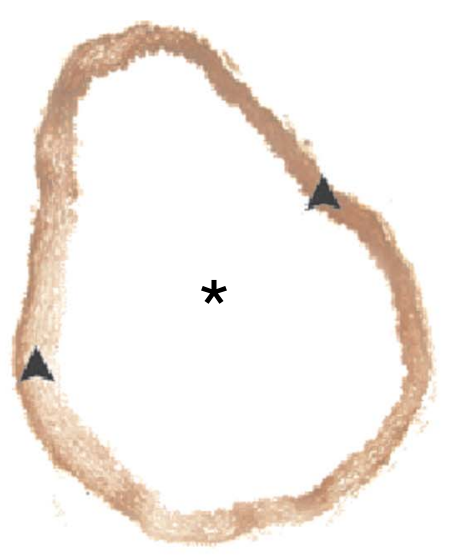

(c)

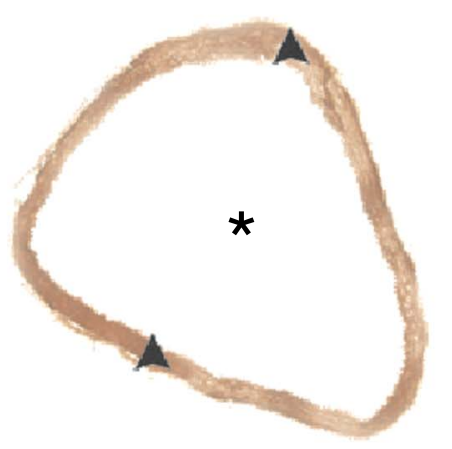

(e)

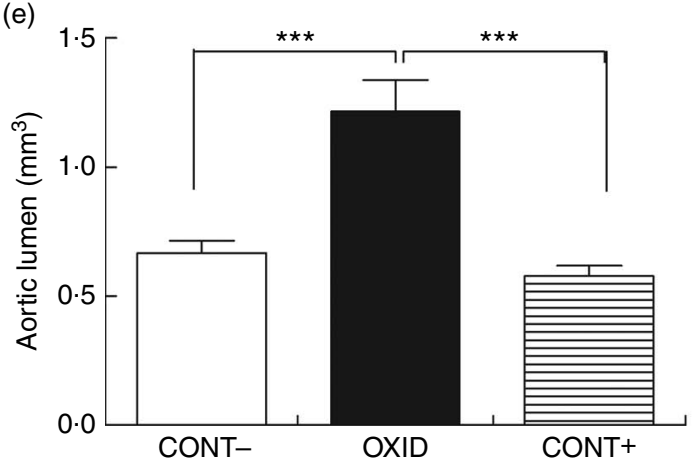

(b)

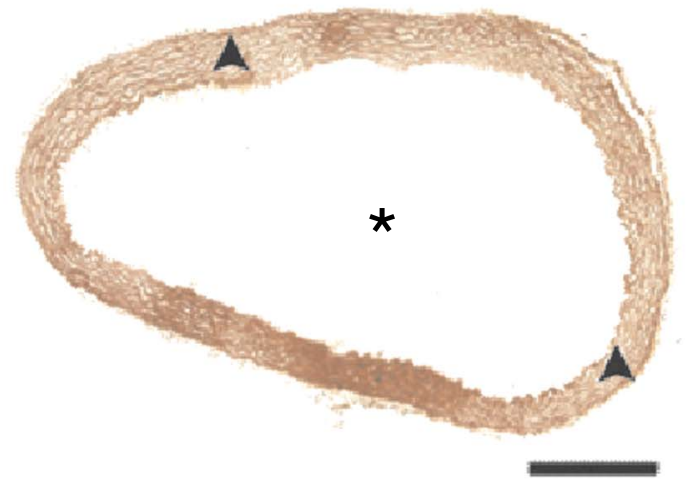

(d)

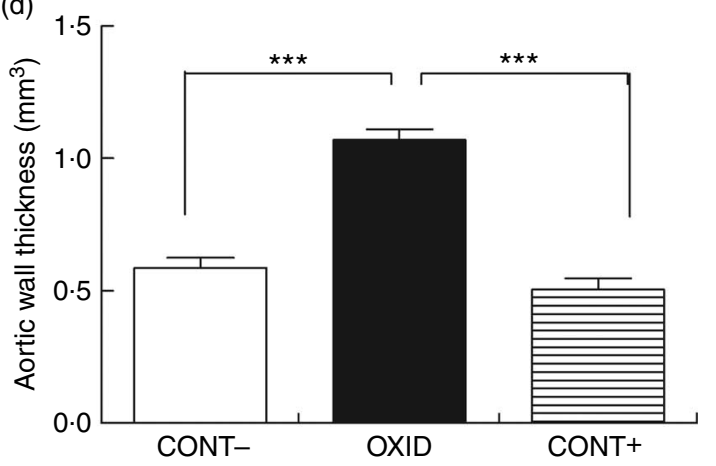

(f)

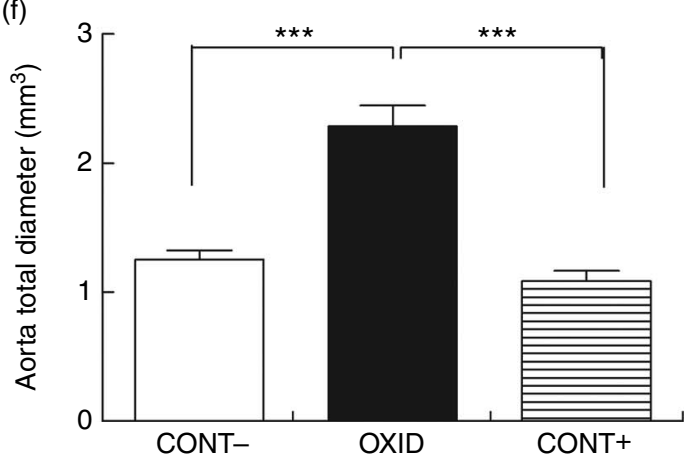

Fig. 4. Representative images of orcein-stained aortas of a high-fat diet prepared with fresh flaxseed oil (CONT-) (a), a high-fat diet prepared with heated flaxseed oil (OXID) (b) and a high-fat diet prepared with fresh flaxseed oil + streptozotocin (CONT+) (c). Values of aortic wall area (d), aortic lumen area (e) and total aorta area (f) are means $(n 5)$, with standard errors represented by vertical bars. ${ }^{* \star *} P<0.001$. ${ }^{*}$, Lumen; $\mathbf{A}$, vessel wall in the range of $50 \mu \mathrm{m}$.

detected in vivo. Although the rate is low, part of the ALA is converted into EPA and DHA during fatty acids metabolism. The same authors reported that EPA-derived J3-IsoPs activates the transcription factor $\mathrm{Nrf} 2$, which leads to antioxidant cytoprotective gene expressions, regulating detoxification of reactive $\mathrm{O}_{2}$ species ${ }^{(10,17,49,60)}$. However, the pro- or anti-atherogenic activity of $n-3$ fatty acids oxidation products, both from the diet or endogenously produced by non-enzymatic reactions, is controversial. The results of more recent investigations have proposed that some products formed by $n-3$ fatty acids peroxidation show biological properties, including anti-arrhythmic, anti-inflammatory and antioxidant effects ${ }^{(61)}$. Thus, as our fourth hypothesis, we suggest that a more severe oxidative stress condition could be obtained by replacing $n-3$ with $n-6$ fatty acids in our model.

Even after assuming an increase in the other oxidative stress biomarkers after oxidised fatty acids intake, regardless of whether they come from an $n-3$ or $n-6$ source, this does not necessarily represent an atherogenic risk. This question was raised in our previous study involving fish oil and oxidative stress ${ }^{(62)}$. For example, Penumetcha et al. ${ }^{(63)}$ fed $\operatorname{LDLr}^{(-/)}$mice a diet rich in $n-6$ fatty acids and observed an increase in oxidative stress, as measured by 8 -iso-PG $\mathrm{F}_{22}$, but negatively associated with aortic lesion, suggesting an adaptive response by increasing antioxidant defence.

It has been suggested that moderate consumption of oxidised fats is safe, but some lipid oxidation compounds might be 
harmful in the long term ${ }^{(54)}$. Our results showed that consumption of oil containing a higher amounts of oxidised PUFA (OXID), associated with a diet containing a larger amount of salt and $\mathrm{Fe}$ and a lower amount of Se, was sufficient to promote an increase in liver MDA equivalent to the concentration observed in the CONT+. Clinically relevant animal models of antioxidant function are essential for improving our understanding of the role of antioxidants in the pathogenesis of complex diseases ${ }^{(6)}$. Considering that MDA can form adducts with lysine residues in apo B, contributing to atherosclerosis progression, the model developed in our study provided an alternative to promote an increase in oxidative stress, without applying severe forms of induction. The concentration of liver MDA expressed as nmol/mg ptn observed in all groups $(3.8 \mathrm{nmol} / \mathrm{mg}$ ptn) was similar to or higher than the values found in other studies that applied xenobiotic agents as inductors, such as Yang et al. ${ }^{(64)}$ using $\mathrm{CCl}_{4}(4.5 \mathrm{nmol} / \mathrm{mg} \mathrm{ptn})$, Zeng et $a l^{(65)}$ applying ethanol $(3.5 \mathrm{nmol} / \mathrm{mg} \mathrm{ptn})$, Ibrahim et $a l^{(45)}$ with a high-fat diet containing more $\mathrm{Fe}$ and without vitamin $\mathrm{E}(2.60 \mathrm{nmol} / \mathrm{mg} \mathrm{ptn})$, Botelho et al. ${ }^{(66)}$ using a high-fat diet with $30 \%$ lard $(2.50 \mathrm{nmol} / \mathrm{mg} \mathrm{ptn})$, Rosa et al. ${ }^{(15)}$ submitting CF1 mice to sham intermittent hypoxia for $35 \mathrm{~d}(1.2 \mathrm{nmol} / \mathrm{mg} \mathrm{ptn})$ and Lin \& Ying ${ }^{(67)}$ using a high-fat diet containing $70 \%$ fat ( $1.4 \mathrm{nmol} / \mathrm{mg} \mathrm{ptn})$. Thus, our model could be further used to evaluate antioxidants and atherosclerosis.

In addition to the rise in oxidative stress in the liver caused by consumption of oxidised flaxseed oil, the OXID group showed an increase in aorta wall thickness, aortic lumen and total aortic diameter, when compared with CONT- and CONT+ groups. As all three groups were fed the same high-fat diet, the difference observed in the OXID group was an isolated consequence of oxidised fatty acids intake. This outward hypertrophy without a reduction in lumen size represents adaptive remodelling in response to a rise in pressure ${ }^{(68)}$. This enlargement can be attributed to fracture of load-bearing elastin fibres caused by pulsatile tensile stress ${ }^{(69)}$. Therefore, this effect on the aorta was an isolated consequence of oxidised PUFA consumption, and could be an adaptive response to an increase in arterial pressure.

In conclusion, our data showed that the long-term consumption of flaxseed oil containing weakly oxidised ALA and LNA can promote oxidative stress in LDLr ${ }^{(-/-)}$mice, measured as liver MDA concentration. Taking into account the new trends to replace pro-inflammatory SFA or $n-6$ fatty acids with anti-inflammatory $n-3^{(70)}$, our study highlights that oils rich in PUFA must be strongly protected from oxidation during their processing and storage. In addition, the diet used in this study represents an improvement in the current model systems and can be applied in future investigations involving antioxidants and atherosclerosis.

\section{Acknowledgements}

This research was supported by the São Paulo Research Foundation - FAPESP (process 14/18697-0) and by the National Council for Scientific and Technological Development - CNPq (process 134621/2013-1).

I. A. C. designed the research protocol; M. S. N. and M. C. K. conducted the research analysis; A. A. B. L. L. and F. V. L. L. carried out the aorta sterological analysis; B. C. performed steatosis analysis; I. A. C. and M. S. N. analysed the data and wrote the manuscript. All the authors read and approved the final version of the manuscript.

There are no conflicts of interest.

\section{References}

1. Libby P, Ridker PM \& Hansson GK (2011) Progress and challenges in translating the biology of atherosclerosis. Nature 473, 317-325.

2. Zaina S \& Lund G (2011) Epigenetics: a tool to understand diet-related cardiovascular risk? J Nutrigenet Nutrigenomics $\mathbf{4}$, 261-274.

3. Rezvan A, Ni CW, Alberts-Grill N, et al. (2011) Animal, in vitro, and ex vivo models of flow-dependent atherosclerosis: role of oxidative stress. Antioxid Redox Signal 15, 1433-1448.

4. Ishibashi S, Herz J, Maeda N, et al. (1994) The two-receptor model of lipoprotein clearance: tests of the hypothesis in 'knockout' mice lacking the low density lipoprotein receptor, apolipoprotein E, or both proteins. Proc Natl Acad Sci U S A 91, 4431-4435.

5. Higley NA, Beery JT, Taylor SL, et al. (1986) Comparative atherogenic effects of cholesterol and cholesterol oxides. Atherosclerosis 62, 91-104.

6. Yu R \& Schellhorn HE (2013) Recent applications of engineered animal antioxidant deficiency models in human nutrition and chronic disease. J Nutr 143, 1-11.

7. Lloyd K, Franklin C, Lutz C, et al. (2015) Reproducibility: use mouse biobanks or lose them. Nature 522, 151-153.

8. Russell JC \& Proctor SD (2006) Small animal models of cardiovascular disease: tools for the study of the roles of metabolic syndrome, dyslipidemia, and atherosclerosis. Cardiovasc Pathol 15, 318-330.

9. Hansson GK \& Libby P (2006) The immune response in atherosclerosis: a double-edged sword. Nat Rev Immunol 6, 508-519.

10. Oikawa D, Akai R, Tokuda M, et al. (2012) A transgenic mouse model for monitoring oxidative stress. Sci Rep $\mathbf{2}, 229$.

11. Ding T, Yao Y \& Praticò D (2005) Increase in peripheral oxidative stress during hypercholesterolemia is not reflected in the central nervous system: evidence from two mouse models. Neurochem Int 46, 435-439.

12. Sakata N, Yoshimatsu G, Tsuchiya H, et al. (2012) Animal models of diabetes mellitus for islet transplantation. Exp Diabetes Res 2012, 256707.

13. Kunitomo M, Yamaguchi Y, Kagota S, et al. (2009) Biochemical evidence of atherosclerosis progression mediated by increased oxidative stress in apolipoprotein E-deficient spontaneously hyperlipidemic mice exposed to chronic cigarette smoke. J Pharmacol Sci 110, 354-361.

14. Kuiper HC, Miranda CL, Sowell JD, et al. (2008) Mercapturic acid conjugates of 4-hydroxy-2-nonenal and 4-oxo-2-nonenal metabolites are in vivo markers of oxidative stress. $J$ Biol Chem 283, 17131-17138.

15. Rosa DP, Martinez D, Picada JN, et al. (2011) Hepatic oxidative stress in an animal model of sleep apnoea: effects of different duration of exposure. Comp Hepatol 10, 1

16. Hermans N, Cos P, De Meyer GR, et al. (2007) Study of potential systemic oxidative stress animal models for the evaluation of antioxidant activity: status of lipid peroxidation and fat-soluble antioxidants. J Pharm Pharmacol 59, 131-136.

17. Flora SJS (2011) Arsenic-induced oxidative stress and its reversibility. Free Radic Biol Med 51, 257-281. 
18. Breslow JL (1996) Mouse models of atherosclerosis. Science 272, 685-688.

19. Jawien J, Nastalek P \& Korbut R (2004) Mouse models of experimental atherosclerosis. I Physiol Pharmacol 55, 503-517.

20. Jové M, Pamplona R, Prat J, et al. (2013) Atherosclerosis prevention by nutritional factors: a meta-analysis in small animal models. Nutr Metab Cardiovasc Dis 23, 84-93.

21. Khan-Merchant N, Penumetcha M, Meilhac O, et al. (2002) Oxidized fatty acids promote atherosclerosis only in the presence of dietary cholesterol in low-density lipoprotein receptor knockout mice. J Nutr 132, 3256-3262.

22. Eder K (1999) The effects of a dietary oxidized oil on lipid metabolism in rats. Lipids 34, 717-725.

23. Kämmerer I, Ringseis R \& Eder K (2011) Feeding a thermally oxidised fat inhibits atherosclerotic plaque formation in the aortic root of LDL receptor-deficient mice. Br J Nutr 105, 190.

24. Awada M, Soulage CO, Meynier A, et al. (2012) Dietary oxidized $n-3$ PUFA induce oxidative stress and inflammation: role of intestinal absorption of 4-HHE and reactivity in intestinal cells. J Lipid Res 53, 2069-2080.

25. Staprans I, Pan X-M, Rapp JH, et al. (1998) Oxidized cholesterol in the diet accelerates the development of aortic atherosclerosis in cholesterol-fed rabbits. Arterioscler Thromb Vasc Biol 18, 977-983.

26. Staprans I, Rapp JH, Pan X-M, et al. (1993) The effect of oxidized lipids in the diet on serum lipoprotein peroxides in control and diabetic rats. J Clin Invest 92, 638-643.

27. Staprans I, Rapp JH, Pan X-M, et al. (1996) Oxidized lipids in the diet are incorporated by the liver into very low density lipoprotein in rats. J Lipid Res 37, 420-430.

28. Staprans I, Pan X-M, Rapp JH, et al. (2000) Oxidized cholesterol in the diet accelerates the development of atherosclerosis in LDL receptor- and apolipoprotein E-deficient mice. Arterioscler Thromb Vasc Biol 20, 708-714.

29. Cao J, Zou X-G, Deng L, et al. (2014) Analysis of nonpolar lipophilic aldehydes/ketones in oxidized edible oils using HPLC-QqQ-MS for the evaluation of their parent fatty acids. Food Res Int 64, 901-907.

30. Frankel EN (2005) Lipid Oxidation. Bridgwater: The Oily Press.

31. Tallman DL \& Taylor CG (2003) Effects of dietary fat and zinc on adiposity, serum leptin and adipose fatty acid composition in C57BL/6J mice. J Nutr Biochem 14, 17-23.

32. Sampey BP, Vanhoose AM, Winfield HM, et al. (2011) Cafeteria diet is a robust model of human metabolic syndrome with liver and adipose inflammation: comparison to highfat diet. Obesity (Silver Spring) 19, 1109-1117.

33. Shantha NC \& Decker EA (1994) Rapid, sensitive, iron-based spectrophotometric methods for determination of peroxide values of food lipids. $J A O A C$ Int 77, 421-424.

34. McDonald RE \& Hultin HO (1987) Some characteristics of the enzymic lipid peroxidation system in the microsomal fraction of flounder skeletal muscle. J Food Sci 52, 15-21.

35. Garcia-Llatas G, Lagarda M, Romero F, et al. (2007) A headspace solid-phase microextraction method of use in monitoring hexanal and pentane during storage: application to liquid infant foods and powdered infant formulas. Food Chem 101, 1078-1086.

36. Shirai N, Suzuki H \& Wada S (2005) Direct methylation from mouse plasma and from liver and brain homogenates. Anal Biochem 343, 48-53.

37. Van Vré EA, van Beusekom HM, Vrints CJ, et al. (2007) Stereology: a simplified and more time-efficient method than planimetry for the quantitative analysis of vascular structures in different models of intimal thickening. Cardiovasc Pathol 16, 43-50.
38. Jordão MT, Ladd FVL, Coppi AA, et al. (2011) Exercise training restores hypertension-induced changes in the elastic tissue of the thoracic aorta. $J$ Vasc Res $\mathbf{4 8}, 513-524$.

39. Hong Y-L, Yeh S-L, Chang C-Y, et al. (2000) Total plasma malondialdehyde levels in 16 Taiwanese college students determined by various thiobarbituric acid tests and an improved high-performance liquid chromatographybased method. Clin Biochem 33, 619-625.

40. Ewing JF \& Janero DR (1995) Microplate superoxide dismutase assay employing a nonenzymatic superoxide generator. Anal Biochem 232, 243-248.

41. Flohe L \& Gunzler WA (1984) Assays of glutathione peroxidase. Methods Enzymol 105, 114-121.

42. Torres LL, Quaglio NB, de Souza GT, et al. (2011) Peripheral oxidative stress biomarkers in mild cognitive impairment and Alzheimer's disease. J Alzheimers Dis 26, 59-68.

43. Kleiner DE, Brunt EM, Van Natta M, et al. (2005) Design and validation of a histological scoring system for nonalcoholic fatty liver disease. Hepatology 41, 1313-1321.

44. Zou Y, Li J, Lu C, et al. (2006) High-fat emulsion-induced rat model of nonalcoholic steatohepatitis. Life Sci 79, 1100-1107.

45. Ibrahim W, Lee U-S, Yeh C-C, et al. (1997) Oxidative stress and antioxidant status in mouse liver: effects of dietary lipid, vitamin E and iron. J Nutr 127, 1401-1406.

46. Staprans I, Rapp JH, Pan X-M, et al. (1994) Oxidized lipids in the diet are a source of oxidized lipid in chylomicrons of human serum. Arterioscler Thromb 14, 1900-1905.

47. Grootveld M, Atherton MD, Sheerin AN, et al. (1998) In vivo absorption, metabolism, and urinary excretion of alpha, beta-unsaturated aldehydes in experimental animals. Relevance to the development of cardiovascular diseases by the dietary ingestion of thermally stressed polyunsaturate-rich culinary oils. J Clin Invest 101, 1210-1218.

48. Uchida K (2000) Role of reactive aldehyde in cardiovascular diseases. Free Radic Biol Med 28, 1685-1696.

49. Adibhatla RM \& Hatcher JF (2010) Lipid oxidation and peroxidation in CNS health and disease: from molecular mechanisms to therapeutic opportunities. Antioxid Redox Signal 12, 125-169.

50. Viana M, Villacorta L, Bonet B, et al. (2005) Effects of aldehydes on CD36 expression. Free Radic Res 39, 973-977.

51. Uchida K (2003) 4-Hydroxy-2-nonenal: a product and mediator of oxidative stress. Prog Lipid Res 42, 318-343.

52. Rains JL \& Jain SK (2011) Oxidative stress, insulin signaling, and diabetes. Free Radic Biol Med 50, 567-575.

53. Agência Nacional de Vigilância Sanitária (Anvisa) (2005) Resolução RDC n 270, de 22 de setembro de 2005. In Regulamento técnico para óleos vegetais, gorduras vegetais e creme vegetal (Technical Regulations for Vegetable Oils, Vegetable Fats and Vegetable Cream), Vol. RDC 270, [A-ANdV Sanitária, editor]. Brasilia: Diário Oficial da União; Poder Executivo.

54. Dobarganes C \& Márquez-Ruiz G (2003) Oxidized fats in foods. Curr Opin Clin Nutr Metab Care 6, 157-163.

55. Negre-Salvayre A, Coatrieux C, Ingueneau C, et al. (2008) Advanced lipid peroxidation end products in oxidative damage to proteins. Potential role in diseases and therapeutic prospects for the inhibitors. Br J Pharmacol 153, 6-20.

56. Esterbauer H, Gebicki J, Puhl H, et al. (1992) The role of lipid peroxidation and antioxidants in oxidative modification of LDL. Free Radic Biol Med 13, 341-390.

57. Vinchi F, Muckenthaler MU, Da Silva MC, et al. (2014) Atherogenesis and iron: from epidemiology to cellular level. Front Pharmacol 5, 328-347.

58. Fairweather-Tait SJ, Bao Y, Broadley MR, et al. (2011) Selenium in human health and disease. Antioxid Redox Signal 14, 1337-1383. 
59. Yin H, Brooks JD, Gao L, et al. (2007) Identification of novel autoxidation products of the $\omega-3$ fatty acid eicosapentaenoic acid in vitro and in vivo. J Biol Chem 282, 29890-29901.

60. Gao L, Wang J, Sekhar KR, et al. (2007) Novel n-3 fatty acid oxidation products activate $\mathrm{Nrf} 2$ by destabilizing the association between Keap1 and Cullin3. J Biol Chem 282 2529-2537.

61. Roy J, Le Guennec J-Y, Galano J-M, et al. (2015) Non-enzymatic cyclic oxygenated metabolites of omega- 3 polyunsaturated fatty acid: bioactive drugs? Biochimie 120, 56-61.

62. Carrepeiro MM, Rogero MM, Bertolami MC, et al. (2011) Effect of $n-3$ fatty acids and statins on oxidative stress in statintreated hypercholestorelemic and normocholesterolemic women. Atherosclerosis 217, 171-178.

63. Penumetcha M, Song M, Merchant N, et al. (2012) Pretreatment with $n$-6 PUFA protects against subsequent high fat diet induced atherosclerosis - potential role of oxidative stressinduced antioxidant defense. Atherosclerosis 220, 53-58.

64. Yang J, Li Y, Wang F, et al. (2010) Hepatoprotective effects of apple polyphenols on CCl4-induced acute liver damage in mice. J Agric Food Chem 58, 6525-6531.
65. Zeng T, Guo F-F, Zhang C-L, et al. (2008) The anti-fatty liver effects of garlic oil on acute ethanol-exposed mice. Chem Biol Interact 176, 234-242.

66. Botelho PB, Guimarães JP, Mariano KR, et al. (2015) Effect of echium oil combined with phytosterols on biomarkers of atherosclerosis in LDLr-knockout mice: echium oil is a potential alternative to marine oils for use in functional foods. Eur J Lipid Sci Tech 117, 1561-1567.

67. Lin C-c \& Yin M-c (2008) Effects of cysteine-containing compounds on biosynthesis of triacylglycerol and cholesterol and anti-oxidative protection in liver from mice consuming a highfat diet. Br J Nutr 99, 37-43.

68. Prewitt RL, Rice DC \& Dobrian AD (2002) Adaptation of resistance arteries to increases in pressure. Microcirculation 9, 295-304.

69. Laurent S \& Boutouyrie P (2015) The structural factor of hypertension large and small artery alterations. Circ Res 116, 1007-1021.

70. van Diepen JA, Berbée JFP, Havekes LM, et al. (2013) Interactions between inflammation and lipid metabolism: relevance for efficacy of anti-inflammatory drugs in the treatment of atherosclerosis. Atherosclerosis 228, 306-315. 